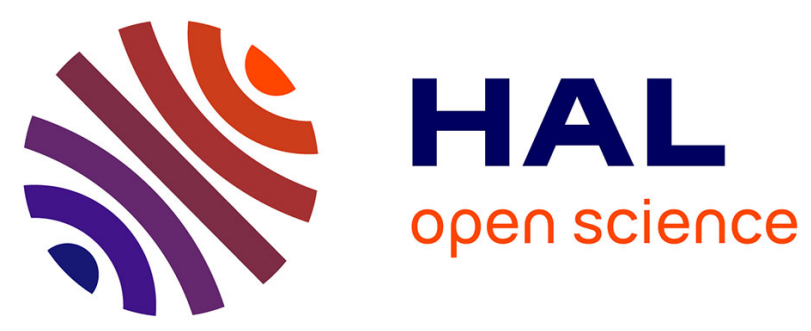

\title{
Maintaining legitimacy in contested mature markets through discursive strategies: the case of corporate environmentalism in the French automotive industry
}

Alain Debenedetti, Déborah Philippe, Damien Chaney, Ashlee Humphreys

\section{To cite this version:}

Alain Debenedetti, Déborah Philippe, Damien Chaney, Ashlee Humphreys. Maintaining legitimacy in contested mature markets through discursive strategies: the case of corporate environmentalism in the French automotive industry. Industrial Marketing Management, 2021, 92, pp.332-343. hal-02493108

\author{
HAL Id: hal-02493108 \\ https://hal.science/hal-02493108
}

Submitted on 4 Mar 2020

HAL is a multi-disciplinary open access archive for the deposit and dissemination of scientific research documents, whether they are published or not. The documents may come from teaching and research institutions in France or abroad, or from public or private research centers.
L'archive ouverte pluridisciplinaire HAL, est destinée au dépôt et à la diffusion de documents scientifiques de niveau recherche, publiés ou non, émanant des établissements d'enseignement et de recherche français ou étrangers, des laboratoires publics ou privés. 


\title{
Maintaining legitimacy in contested mature markets through discursive strategies: the case of corporate environmentalism in the French
}

\section{automotive industry}

\author{
Alain Debenedetti, Université Gustave Eiffel, Institut de Recherche en Gestion \\ Déborah Philippe, University of Lausanne, Faculty of Business and Economics \\ Damien Chaney, South Champagne Business School, Laboratoire Regards \\ Ashlee Humphreys, Northwestern University, Medill School of Journalism
}

\begin{abstract}
Market-level studies based on institutional theory have gained prominence in recent marketing research seeking to investigate legitimation dynamics. Although these studies have paid particular attention to how organizations build legitimacy in new markets, they have rarely explored legitimations strategies in mature markets, which mostly remain the prerogative of organizational theory. Such emphasis on new markets is thus limiting our understanding of legitimation dynamics in general and legitimacy maintenance in particular, especially since new and mature markets have different characteristics. When markets are well established, they tend to become the target of a growing number of contestations by actors seeking to introduce new societal issues. Once these issues have been institutionalized, organizations must address them to maintain their legitimacy. In this study, we investigate the discursive strategies used by the French carmakers when environmental considerations gained prominence between 2006 and 2008. In contrast to prior works in organizational theory which assume that organizations respond to institutional pressures in an undifferentiated way, our results show that organizations adopt differentiated legitimation strategies by adapting their discourse to their different stakeholders. Paradoxically, we find evidence of industry-wide isomorphism, where rather than developing idiosyncratic discourses, organizations adopt conventional discursive strategies.
\end{abstract}

Keywords: Legitimacy; Discursive strategies; Environmentalism; Contested markets; Mature markets; Institutional theory 


\section{Introduction}

Market-level studies based on institutional theory have gained prominence in recent marketing research to account for the importance of legitimation processes (e.g. Ertimur and Coskuner-Balli 2015; Humphreys, 2010; Palmer et al. 2015). This broader approach to markets, which goes beyond a microeconomic and consumer-centric perspective, theorizes markets as "the result of discursive negotiations among...stakeholders" (Giesler and Fischer 2017, p.3). In particular, prior research has discussed how organizations use discursive strategies, i.e. the production and diffusion of communication that actors use to render events and actions meaningful (Phillips, Lawrence, and Hardy 2004) to legitimize themselves. Although the marketing literature has paid particular attention to how organizations build legitimacy in new markets (e.g., Ertimur and Coskuner-Balli 2015; Humphreys 2010; Martin and Schouten 2013), the question of legitimacy maintenance in mature ones has remained almost exclusively the focus of research in strategic management or organizational theory (e.g., Elsbach 1994; Kostova and Zaheer 1999; Patriotta, Gond and Schultz 2011; Powell and DiMaggio 1991). Such emphasis of the marketing literature on new markets has overshadowed a deeper understanding of organizations' legitimation strategies in mature markets, in particular since new and mature markets have different characteristics, likely to impact legitimation processes.

New markets, which are in the process of being structured, function differently than mature markets, characterized by recognized products and established fields (Maguire, Hardy and Lawrence 2004). The literature suggests that new markets are primarily shaped by products, services, or technologies (DiMaggio and Powell 1983) and that organizations embedded in such markets must work at legitimating the market as a whole in order to make its products cognitively understandable, morally acceptable and legally compliant (e.g., Humphreys 2010). These questions, however, become less important in mature markets, 
which tend, at some point, to organize around societal issues. According to Hoffman (1999, p. 352), "issues define what the field is, making links that may not have previously been present." Issues can be defined as sensitive, potentially destabilizing questions that become institutionalized as organizations recognize them as important topics. If these issues reach the status of social norms, i.e., "powerful behavioral standards whose function is to summarize the behavior of a reference group" (Philippe and Durand 2011, p. 970), organizations are expected to conform to these norms in order to maintain their legitimacy in the eyes of their stakeholders and ensure their performance and survival (Oliver 1991). For instance, while obesity, food waste, data protection and pesticide can be important issues in some fields, environmentalism has become transversal to many industries and therefore a critical element to almost all organizations' image (Banerjee, Iyer, and Kashyap 2003; Menon and Menon 1997; Sharma et al., 2010). Several scholars have shown that corporate environmentalism has grown over the past three decades into a "normative institutional pillar" and a "matter of social obligation" (Hoffman 1999, p. 363), thus prompting organizations to integrate environmentally-friendly practices into their activities (e.g., Banerjee, Iyer, and Kashyap 2003; Czintoka, Kaufmann and Basile 2014; Menon and Menon 1997).

Furthermore, while previous studies in organization theory have documented the ways through which organizations try to discursively maintain their legitimacy in mature contested market, they tend to assume that organizations respond to institutional pressures in an undifferentiated way with respect to their audiences (Elsbach 1994; Oliver 1991). We argue, however, that the introduction of an issue like environmentalism in a mature market requires an adaptation of the response strategy because stakeholders may have different positions about the issue (Maignan and Ferrell 2004). As a consequence, we raise the following research question: how do organizations discursively maintain their legitimacy in mature contested markets in the eyes of multiple audiences? 
To answer this question, we draw on the notion of discursive strategies to investigate how organizations build different discourses to legitimate themselves when facing key issues in their market. We investigate the case of environmentalism in the French automobile industry during the 2006 to 2008 period, when the issue gained prominence, and we examine how the French carmakers negotiated this societal shift in their communication with their three primary constituents (i.e., customers, employees and shareholders). Our study contributes to the marketing literature that investigates legitimation processes by showing that the legitimation dynamics in mature markets significantly differ than those in new markets. In particular, we contribute to the literature on the discursive maintenance of legitimacy by showing, first that in a mature and contested market, organizations' legitimacy is tied to key social issues and second that organizations need to rely on differentiated discursive strategies and frame their responses to the social issue they face according to their targeted audience.

Specifically, our research complements prior works on the discursive maintenance of legitimacy by showing that the legitimation dynamics in mature markets differ significantly from the legitimation dynamics in earlier stages of markets. In particular, our findings point to two key differences: the re-structuration of markets around key issues; and the adaptation of organizational discourses to address the different expectations of their stakeholders.

The remainder of the article is organized as follows: we start by presenting the concept of legitimacy in mature markets and discussing the relevant literature on discursive strategies before describing our empirical field and research methods. We then present our findings and conclude by discussing several implications for researchers and managers, enumerating avenues for future research.

\section{Conceptual Background}

\subsection{Mature Organizational Fields, Issues and Legitimacy}


Through the lens of institutional theory, markets are conceptualized as organizational fields defining as all the "organizations that, in the aggregate, constitute a recognized area of institutional life: key suppliers, resource and product customers, regulatory agencies, and other organizations that produce similar services and products" (DiMaggio and Powell 1983, p. 148). If societal and political issues partake market dynamics at all stages of their development, Hoffman (1999) suggests that nascent market are primarily driven by technology and/or product whereas mature markets are more likely to be driven by issues. As a consequence, different contesting actors try to bring currently non-addressed issues into the market (King and Pearce 2012). As market actors recognize them, these issues become social norms to which firms must conform. Among important issues such as food waste or data protection, environmentalism has become a critical element to almost all organizations' image (Banerjee, Iyer, and Kashyap 2003; Menon and Menon 1997; Sharma et al., 2010). Hoffman (1999) depicts how environmentalism has become a key issue in the organizational field of the US chemical industry. Specifically, he emphasizes how, since the 1960 s, the chemical industry has undergone deep changes that started with the publication of Silent Spring, Rachel Carlson's famous book on the harmful effects of pesticides. While US chemical organizations initially tried to stay away from the debate, they were gradually forced to engage with the topic. As a result, environmentalism gradually shifted industry norms, as evidenced when chemical organizations began to address the issue of environmentalism in their annual reports, to develop pollution-reduction programs, and to hire environment managers in the $1980 \mathrm{~s}$ (Hoffman 1999).

Within its institutional environment, an organization relates to many constituents or forces that pressure it into adopting socially defined standards of behavior, which are driven by a search for legitimacy (Yang and Su 2014). Legitimacy refers to the "generalized perception or assumption that the actions of an entity are desirable, proper, or appropriate 
within some socially constructed system of norms, values, beliefs, and definitions" (Suchman 1995, p. 574). Suchman (1995) distinguishes between three types of legitimacy—pragmatic, moral, and cognitive - that all involve perceptions that an organization's activities are socially desirable and appropriate but rest on different behavioral mechanisms. Pragmatic legitimacy is an interest-based type of legitimacy that rests on the self-interested calculations of an organization's constituents. The challenge for an organization is thus to persuade its constituents of the usefulness of its behavior (Ashforth and Gibbs 1990). For example, WalMart, by emphasizing in its communication its efforts to propose everyday food and nonfood merchandise at the lowest possible price, is likely to be perceived by its customers as a legitimate entity, based on pragmatic grounds (Arnold, Kozinets, and Handelman 2001). Moral legitimacy is a values-driven type of legitimacy that rests on positive normative judgments about how the organization contributes to the general social welfare. Unlike pragmatic legitimacy, which rests on assessments of narrow self-interest satisfaction, moral legitimacy reflects evaluations of whether the organization is doing "the right thing" in a socially constructed system of values and beliefs. Social fit is achieved when constituents perceive that the organization's activities are driven by a "prosocial logic" (Suchman 1995, p. 579). For instance, Handelman and Arnold (1999) demonstrate that an organization's socially-oriented actions lead to an increase in legitimacy, based on moral grounds. Cognitive legitimacy requires very little explicit legitimization. Rather, it is derived from a long-term fit between an organization and its institutional environment, based on habitual behavioral patterns. It refers to the codified body of knowledge and belief systems that specify the rules of the game in a given institutional field, and it operates mainly at the tacit or subconscious level (Palazzo and Scherer 2006). Legitimacy is acquired through the acceptance of the organization, based on taken-for-granted social accounts. For instance, because it is assumed that certification standards are correlated to quality, an organization that communicates on the 
certification of its products or processes will automatically be associated with an image of quality and will thus be granted legitimacy, based on cognitive grounds (see for instance Rao 2002).

According to institutional theory, acquiring but also maintaining legitimacy when the market is contested is a key concern for organizations since being legitimate leads to an enhanced ability to acquire resources, increased survival chances, avoidance of evaluation and questioning by audiences, and if evaluation occurs, insurance that it will be favorable to the organization (DiMaggio and Powell 1983; Lounsbury and Glynn 2001; Suchman 1995). Being or appearing to be illegitimate, in contrast, entails penalties and sanctions (Zuckerman 1999). While previous research recognizes the importance of discursive strategies in legitimation processes, we argue the dynamics of creating versus maintaining legitimacy are likely to be different and therefore that organizations will develop different discursive strategies.

\subsection{The Discursive Maintenance of Legitimacy}

To shape audiences' perceptions and understanding, organizations rely on the purposeful crafting of language through discursive strategies. Discursive strategies can be defined as the production, and diffusion of texts that create or transform the cognitive schemas through which actors interpret and give meaning to reality (Phillips, Lawrence, and Hardy 2004). The notion of texts is here not limited to written documents but reflects all of the communication documents produced by the firm (Fairclough 2003). Because legitimacy is based in part on the interpretation of organizations' actions (Suchman 1995), discursive strategies aim at conveying explanations of, and rationales for, them (Lounsbury and Glynn 2001). Discursive strategies have been particularly used to build legitimacy (Golant and Sillince 2007; Humphreys 2010). In new markets, previous studies have shown how organizations may gain 
legitimacy by making the whole product category socially accepted (Humphreys 2010; Rosa et al. 1999). In such contexts, discourse fills a void by turning unfamiliar forms or practices into familiar, understandable and acceptable ones (Lounsbury and Glynn 2001) and legitimacy is established through this familiarization process.

In mature markets, the literature has highlighted organizations' efforts to protect and maintain their legitimacy (Elsbach 1994; Kostova and Zaheer 1999; Patriotta, Gond and Schultz 2011), especially when these markets and organizations embedded in them are contested by actors seeking to bring about social change (King and Pearce 2010). The legitimacy of the organization and the market then has more prominent political stakes. Thus, when contested, mature markets in particular become the subject of a struggle between actors who want to introduce new issues into the field and incumbents who seek to defend and maintain their legitimacy (Humphreys, Chaney, and Ben Slimane 2017). For instance, when the DDT market was attacked because of its harmful effects on the environment, organizations focused on discrediting scientific studies about the product in order to maintain their legitimacy (Maguire and Hardy 2009). While these studies have documented the ways through which incumbents try to discursively counter attacks against their markets, they only study the global and undifferentiated response of organizations.

Yet according to an institutional perspective, some actors have more power than others in conferring legitimacy (Deephouse 1996). Indeed, customers as buyers and end users of the product (Humphreys and Latour 2013), employees as active members of the organization (Glavas and Godwin 2013), and shareholders as owners of the organization (Fiss and Zajac 2006) have been shown to be powerful actors in their ability to confer legitimacy, and they each have different influences and interests. Kotter and Heskett (1992) specifically argue that organizations taking the interests of these three specific constituency groups (i.e., employees, customers, and shareholders) into account significantly outperform —in terms of both 
revenues and stock prices - those that focus on only one or two of these groups. When a new issue is introduced into an organizational field, these groups of actors may react differently according to their position in the field. Therefore, although securing the endorsement of these powerful actors is essential for a firm to maintain its legitimacy, it is likely that such legitimation strategy requires adapting the firm's discourse to its different constituents.

The marketing literature on Corporate Social Responsibility (CSR) has shown that an organization' stakeholders may have different norms and standards (Dunfee, Smith and Ross 1999). Because of their position within the field, their values and their interests, these stakeholders' expectations with regards to social issues may significantly differ (Dawkins and Lewis 2003), even to the point of conflicting with each other (Maignan and Ferrell 2004). Taking these different expectations into account should lead organizations to adapt their discourses to their targets. This question, however, has remained relatively neglected in extant literature. We seek to address this gap by examining the discursive strategies deployed by organizations to address the environmental issues they are facing in their market and to which extent these strategies are adapted to their three main constituents: customers, employees and shareholders.

\section{Methods}

\subsection{Research Context}

We explore the question of how organizations discursively maintain their legitimacy in mature markets in the context of corporate environmentalism, which refers to "the recognition and integration of environmental concerns into a firm's decision-making process" (Banerjee, 2002, p. 177). Environmentalism has become a "matter of social obligation" (Hoffman 1999, p. 363) and thus a crucial element of organizations' image (Menon and Menon 1997; Sharma et al., 2010). We investigate the French automobile industry and more specifically how 
carmakers in the field have dealt with the issue of environmentalism. This case is particularly suitable for our purposes for three reasons. First, the automobile industry is particularly exposed to environmental issues. Since the introduction of the first European standard on emissions from combustion-engine vehicles in 1992, carmakers are often accused of contributing to greenhouse gas emissions. In Europe, for instance, cars contribute to more than $70 \%$ of the transportation-related carbon dioxide $\left(\mathrm{CO}_{2}\right)$ emissions. Hence, the industry is under close scrutiny in the global warming debate, and is regularly in the spotlight (e.g. Volkswagen case in 2015). The issue of environmentalism has thus become a defining element of the field on which organizations have to maintain legitimacy. Second, during the past decade -and more specifically in the middle of the 2000s — the French automobile industry underwent a cultural shift. Whereas carmakers were primarily expected to manufacture safe cars in the past (Rao 2002), they are now also required to produce environmentally friendly cars (although safety still remains a necessary characteristic of consumer demand), and environmental considerations have little by little become central to their value proposition. Because this shift is less determined by economic circumstances than it is required by cultural and social pressures, the nature of competition in the automobile industry has been significantly altered. Third, for car manufacturers, the presence of numerous and powerful stakeholders with potentially diverse positions regarding environmental issues (e.g., the government, customers, shareholders, the media) creates a context in which legitimation strategies are important and visible.

The French automobile industry comprises two carmakers, PSA Peugeot Citroën and Renault. PSA Peugeot Citroën was born from the merger in 1976 of two French historical firms, Peugeot created in 1896 and Citroën created in 1919. The Peugeot and Citroën brands, although belonging to the same group, still exist and are marketed separately. Renault was created in 1899. These firms have been accounted for more than half of the French car market 
for decades. These two organizations are also known for their leadership in the production of low-emission cars.

We studied the legitimation strategies of these two firms from 2006 to 2008 . We chose this timeframe because it followed the 2005 rapid growth of press articles about environmental issues in French magazines, and because during this three-year period, several environmental regulations were introduced in the French automobile industry, all of which had a significant impact on carmakers' activities at the national level. We studied the legitimation strategies of these two organizations from 2006 to 2008 . We chose this timeframe because the issue of corporate environmentalism started to gain significant attention in the French media and because during this three-year period, several environmental regulations were introduced in the French automobile industry, all of which had significant impact on carmakers' activities at the national level. For instance, in 2006, the French government introduced the " $\mathrm{CO}_{2}$ car labeling" regulation, where each new car had to display a label indicating its level of $\mathrm{CO}_{2}$ emissions. In December 2007, the government implemented an ecological "feebate" system for the purchase of new cars, wherein buyers of low-emitting vehicles are rewarded by substantial rebates on the car price, while buyers of high-emitting cars are penalized by additional fees. These growing environmental concerns were also addressed at the European level, with debates opposing the French and German car makers on the extent to which coercive measures should be implemented. While the German firms, which produce larger and more polluting vehicles than French ones, advocated for a possible compensation of $\mathrm{CO} 2$ emissions between firms, and for a modulation of the penalty based on the number of vehicles produced, French manufacturers called for penalties based on the $\mathrm{CO} 2$ emissions of each individual car. However, regulation is not the only driver of environmentalism in our case study: corporate environmentalism emerges as a central issue because NGOs, consumers or researchers made it visible in the mass media. For example, 
before and during this focal period, newspaper articles on environmentalism dramatically increased in France, revealing a fast-growing interest about environmental issues starting in 2002 and reflecting the shift in the French cultural norms around environmental issues (Table 1). Given the increased environmental pressures facing the car industry during this period, it was deemed an appropriate window of observation to study carmakers' processes of legitimation.

Insert Table 1 around here

\subsection{Data Collection and Analysis}

The data collection spans 36 months, from January 2006 to December 2008. For the purpose of this multi-constituent study, we collected data from several sources that overall include 1,534 printed ads and over 2,000 pages of textual information from internal magazines and annual reports. We sampled both internal and external communications to stakeholders. For internal part of communication, we collected 36 months of the organizations' in-house monthly newsletters to employees (Planète Groupe for PSA Peugeot Citroën and Global for Renault), from January 2006 to December 2008. To study external communication, which was targeted at shareholders and financial analysts, we collected PSA Peugeot Citroën's and Renault's annual reports for fiscal years 2006, 2007, and 2008. For the customer-oriented communication, we identified 11 French magazines that were representative of the two main strategic positioning in car advertising (i.e., image-focused and promotion-focused) with the help of a senior media-planner. Data were collected at the brand level, as it is consistent with marketing communication practices at customers' level. For the purposes of our study, we over-represented the image-focused journals in the sample. These 11 magazines were chosen because they belonged to the top 30 of automobile ad insertions in French magazines in 2008 . 
We then carried out the data analysis in five main stages. In the first phase, we started by identifying relevant material based on Wilmshurst and Frost's (2000, p. 16) definition of environmental disclosures as those "that relate to the impact company activities have on the physical or natural environment in which they operate.” In the employee-oriented communication, we identified a total of 142 environment-related items (i.e., articles, short notes, files, interviews) - 72 for PSA Peugeot Citroën's Planète Groupe newsletter and 70 for Renault's Global newsletter. For the customer-oriented communication, we identified a total of 65 ads that mentioned the natural environment (which represented a total of 363 insertions) $)^{2}-35$ (131 insertions) for Peugeot; 12 (90 insertions) for Citroën, and 19 (142 insertions) for Renault. These environment-related ads represented about $20 \%$ the firms' total advertising insertions of the 2006-2008 period. For our analysis of communications that were targeted to shareholders, we focused on the narrative sections of the six annual reports ${ }^{3}$. To ensure comparable computer-readable data across all communication media, we transcribed the content of the in-house newsletters, the narrative sections of the annual reports, and the textual elements of the magazine ads into electronic digital files. The visual elements were coded separately.

In the second phase of the data analysis, we selected the relevant units of analysis. Given the much-differentiated nature of the investigated sources, we used different coding units across our material. For the annual reports and the in-house newsletters' articles, we defined our coding unit as meaning units, that is, the collection of words, sentences or paragraphs relating to the same central meaning. Annual reports and newsletters respectively yielded a total of 437 and 174 units of analysis. For the magazine ads, we identified 5 possible coding units—slogan, text message, background image, typography, and iconic symbols. Our ad analysis yielded a total of 778 units after being weighted by the number of total insertions of the ad (Table 2). 
Insert Table 2 about here

In the third phase, we performed a content-analysis (Krippendorff 1980; Weber 1985) of these different elements to identify the discursive strategies that organizations employed to talk about their environmental behavior ${ }^{4}$. The initial coding scheme was produced through examination of several items of each source category (report, in-house newsletter, magazine ads). This inductively developed coding scheme was kept open for new codes that emerged during the coding process (Strauss and Corbin 1990). The content-analysis performed on the textual elements of the data resulted in the identification of several themes (e.g., compliance to norms, technological leadership, or sponsorship). For the graphic/iconic components, we coded diverse elements (e.g., choice of colors, urban versus natural background, iconic symbols). To ensure the internal validity of the coding process, the authors coded the whole dataset independently. This double coding procedure enabled us to directly assess interrater reliability. The interrater agreement has a kappa statistic of 0.74 for the in-house newsletters, 0.80 for the ads, and 0.92 for the annual reports. For any discrepant ratings, we easily came to an agreement and reached full consensus.

The fourth step of this analysis consisted of theoretically coding — categorizing each theme or element (Krippendorff 1980; Strauss and Corbin 1990) as belonging to either the pragmatic, moral, or cognitive type of legitimacy (Suchman 1995). Specifically, we considered that disclosures were framed in a pragmatic way when the environmental cues focused on the audience's personal rewards. Moral framing referred to environmental cues focused on altruistic rewards (i.e., with the environment as the beneficiary). Eventually, we considered that environmental cues that presented de-contextualized and taken-for-granted facts fell into the category of cognitive framing. If an element included two types of legitimacy, it was coded in both categories. 
Fifth, in order to get a sense of the effectiveness of the firm's discursive strategies, we performed an additional analysis, following Philippe and Durand (2011)'s analyses on media tonality. Media favorability has traditionally been defined as reflecting the "overall evaluation of a firm" (Deephouse 2000, p. 1097). Media favorability or tonality can thus be used as an indicator of firm legitimacy. To calculate this indicator, we screened all the data obtained from a Factiva search (all the articles in French mentioning the terms "industry", "automobile", "environment" and at least one firm of our list from 2006 to 2009, 2009 being added to integrate the effect of 2008 firms' environmental actions and discourses on media coverage $^{1}$ ). From the remaining dataset, we identified 401 relevant units, which we coded according to the valence (positive, negative of neutral) of their disclosures associating the firms to their environmental actions and/or narratives. We attributed equal weight to each unit, and following Philippe and Durand (2011), we created an environmental legitimacy measure for each firm using the Janis-Fadner coefficient of imbalance. Specifically, we calculated the relative number of positive (p) and negative (n) mentions of a firm's environmental behavior in a given period using the formula: $(p 2-p \cdot n) /(p+n) 2$ if $>n ; 0$ if $=n$; and $(p . n-n 2) /(p+n) 2$ if $>$ p. In this procedure, the measure ranges from -1 to 1 , where -1 indicates all negative coverage (i.e., illegitimacy), 1 equals all positive coverage (i.e., full legitimacy), and 0 is a balance between the two. As for customer-oriented communication, this coefficient was calculated for each brand as media tend to focus on brands rather than on groups.

\section{Findings}

Our analysis of firms' legitimation strategies around environmentalism led to the identification of three different discourses - targeted to the specificity of the different

\footnotetext{
${ }^{1}$ This additional and exploratory data collection resulted in retrieving 2,962 pages of printed documents
} 
stakeholders - that build on the three types of legitimacy (i.e., pragmatic, moral, and cognitive), although in different ways (Figure 1). Although our findings show that firms adapt their discourse to their stakeholders, the discursive strategies across firms are surprisingly similar. This is particularly striking in the case of customer-targeted communication where companies would be expected to differentiate themselves from their competitors. Illustrative quotations are provided in Table 3.

When looking at how these three organizations are portrayed by the media in relation to environmental issues, their communication strategies appear to be successful. The three firms are depicted in a favorable way in the media, as shown by the Janis Fadner coefficients respectively obtained by Peugeot (0.75), Citroën (0.71) and Renault (0.58). These results also show that the three firms' evaluation is quite similar, suggesting a discursive isomorphism between these firms that we do not find in the discursive strategies directed to stakeholders.

Insert Figure 1 about here

\subsection{Customer-Targeted Environmental Legitimation Strategy: An Individuation Discourse}

To maintain their legitimacy in the eyes of customers, firms rely on an autonomy-based discourse which builds on the three types of legitimacy - pragmatic, moral and cognitive (Suchman 1995). As summarized in Table 2, although firms could have built on a balanced use of these three types, we find that cognitive and pragmatic legitimacy are the dominant discursive strategies.

The moral references that are present in the slogans and texts of the ads at the beginning of our study period tend to lose visibility at the end and are removed from the slogans, moving the moral message from explicit to implicit. Moral legitimacy is expressed first through an emphasis on the organization's commitment to environmental stewardship and involvement in environmentally friendly initiatives, and second through allusions to the 
customers' potential contributions to global environmental welfare and the additional satisfaction they can derive from their own altruistic behavior. As suggested by prior research, symbolic rewards associated with moral-based decision-making are likely to contribute to customers' self-definition and self-esteem, thereby underlining their personal and unique identity (Haws, Winterich, and Naylor 2014). Legitimacy is constructed on the basis of a "Be good, be green" motto that reinforces the customer's sense of self-affirmation and autonomy.

We find evidence of pragmatic references mainly within slogans but also marginally within the accompanying text. This discursive strategy exclusively focuses on the intrinsic benefits that customers can derive from buying and driving a green car. In the former case, it emphasizes the monetary rewards that customers can derive from the government's feebate policy, from tax reductions (for company cars), and from a reduction in fuel consumption. In the latter case, emphasis is placed on the recreational aspects of driving a green car, clearly suggesting that the performance of the car and the pleasure customers can derive from driving it are not threatened by more environmentally friendly engines. The social fit is built on a "Be smart, be green" motto that stresses the financial and emotional benefits that environmentally responsible cars are likely to provide.

The cognitive references are dominant in the individuation discursive strategy. Since what customers know about an organization (i.e., the image they form about it) can influence their perceptions of and attitudes toward this organization's products and brands (e.g. Berens, Van Riel, and Bruggen 2005), companies actively choose to portray themselves as socially desirable actors in the realm of environmental stewardship through both textual and graphic/iconic elements, with non-verbal cues representing about half the cognitively framed environmental disclosures. Slogans and text are based mainly on taken-for-granted assertive statements about the organization's environmental policies references to its private environmental labels, and environmental certifications. These slogans and texts also include 
recurring terms that refer to technologies that were considered environmentally friendly (e.g., particulate filter, biofuels, energy-saver tires etc.) in the mid 2000s. Our analysis of nonverbal cues reveals a tendency of organizations to employ green and blue colors in the typography, as well as background images that picture the car in a natural area (e.g., desert, forest) or icons in the shape of flowers or clouds, which refer to the vehicle's environmentally friendly technical attributes. These cues work by association and co-presence rather than by explicit rationalizing or explanation. Here legitimacy is built on a "Be aware, be green" motto and is fostered through the environmental education of customers. More specifically, the presence of environmental cues (which do not necessarily refer to a specific car but often refer to environmentally friendly technologies on a broader level) aim at increasing customers' general level of environmental awareness and, thereby, their identity as informed customers (relative to other less-informed customers).

\subsection{Employee-Targeted Environmental Legitimation Strategy: An Affiliation Discourse}

In the case of the employees, our data indicate that the maintenance of legitimacy on the issue of environmentalism is built through an affiliation-based discourse that emphasizes perceptions of shared values and beliefs towards the firm. This discourse, which shares strong connections with the identification process (Glavas and Godwin 2013; Tajfel 1982), is generally described as comprising two interrelated dimensions - analytical and affective. The analytical dimension refers to the extent to which employees perceive themselves as belonging to the organizational group (Ashforth and Mael 1989), while the affective dimension refers to the sense of pride that accrues to employees as a result of their group membership (Tajfel 1982). In our data, we find evidence that organizations have recourse to the three types of legitimacy to leverage both dimensions of the affiliation process. The cognitive references dominate the other two strategies over the period (see Table 2). However, 
proportionately, the moral dimension is used more for employees than any other stakeholder group.

The moral references present the organization as a social actor, not just as an economic one. It builds on both dimensions of the affiliation process as it aims at strengthening the employees' perceptions of group belongingness while also enhancing their sense of pride towards the firm. Morally oriented disclosures, which emphasize the organization's green citizenship, encompass several issues, such as environmental sponsorship and involvement in climate change-related programs. On the one hand, the inhouse newsletter is used as a tool to emphasize the participation of organizations' employees in various environmental actions and programs, with their involvement being set up as an example and receiving significant coverage and praise. This moral-based discourse clearly relies on the analytical dimension of the affiliation process: employees can define themselves as a group member. On the other hand, this discourse also builds the image of a firm that has internal, local, and global positive impacts on the protection of the natural environment, an image of the organization employees can be proud of. The newsletter conveys information on the organization's involvement in building or supporting green initiatives that are related to car manufacturing activities, or go beyond their activities such as the protection of wildlife.

The pragmatic references explicitly build on the affective dimension of the affiliation process. This strategy, which aims at enhancing the employees' sense of pride towards the company, relies on two main strategies: compliance to norms and efficient use of energy consumption. First, in-house newsletters present environmental issues as an economic challenge for the organization and show how the organizations both conform to the norms and regulations by reducing their polluting emissions (e.g., $\mathrm{CO}_{2}$ or nitrogen oxides) and explain how they go beyond mere norm-compliance by proactively anticipating market and institutional demands (e.g., pollution reduction through the development of efficient 
technologies). Second, environmental pragmatism is also conveyed through numerous mentions of the reduction of energy or resource consumption (e.g., less water or coating employed per vehicle manufactured) in the production facilities. In both instances, the narrative emphasizes the organization's ability to combine and reconcile regulatory challenges and market opportunities, production efficiency and respect for the environment, and, on a broader level, economy and ecology. These pragmatic references build the image of a proactive and smart company, one that is able to draw benefits from social expectations and legal norms. Employees can easily feel proud of being part of a "smart" firm.

Eventually, we find that the cognitive references similarly build on the affective dimension of the affiliation process. The organization's environmental leadership, the implementation of in-house green labels, and commitments to future environmental performance are considered taken-for-granted environmentally friendly information. Environmental leadership is the most frequently mentioned theme and is expressed through a large array of messages that emphasize the organization's good ratings and rankings on its environmental performance (e.g., Fortune magazine) and its pioneering actions in the domains of environmental certification of plants, use of environmental labeling on its products, participation in environmental tradeshows, and changes in the organizational structure to support cross-departmental environmental actions. The references that build cognitive legitimacy emphasize the implementation of in-house green labels. Eventually, employee-targeted disclosures emphasize the organization's future commitments towards protecting the environment and maintaining environmental leadership. This cognitive-based discourse emerges as the dominant strategy over the observation period.

\subsection{Shareholder-Targeted Environmental Legitimation Strategy: A Performance Assertion Discourse}


When building a social fit with its shareholders regarding environmentalism, we find that an organization is likely to use a process that is based on performance assertion. Once again, this mechanism relies on the use of the three types of legitimacy. Cognitive and pragmatic references are dominant in this discursive strategy (See Table 2).

The moral references are virtually absent from annual reports. When used, this discursive strategy can, however, be considered as a source of brand equity development, based on corporate environmentalism. Morally oriented disclosures mainly allude to environmental sponsorship and involvement in environmental research programs. Such communication indirectly suggests that the organization's altruistic behavior and the pertaining brand associations that it triggers among its constituents are likely to increase the value of the corporate brand.

The pragmatic references clearly and more directly put the emphasis on corporate environmentalism as an opportunity for profit, increased competitive position, risk management with regards to norm compliance, and reduction of energy and resource consumption during manufacturing processes. Such a positioning somehow parallels the pragmatic discursive strategy that is used with employees, but the message here is focused on profit generation rather than solely on cost management. Being green is not simply a smart way of saving money; it is also a source of competitive advantage and increased financial performance.

Although the cognitive references aim mainly at distilling the idea of the organization's proactive behavior towards environmental issues, it encompasses a wide variety of issues. We found some similarities between the employee- and customer-targeted communications in the form of an emphasis on environmental leadership and adoption of environmental certifications. However, the cognitive-based discourse also relies on two different mechanisms: endorsement by and partnerships with environmentally reputed 
entities, and environmental exemplarity. Partnerships can be scientifically rooted, in which case they will take the form of research labs (e.g., France's National Scientific Research Centre), or they can be para-governmental entities (e.g., Atomic Energy Commission, National Forest Office etc.). They can also consist in giving the firm a scientific caution through a commissioned article written by a noteworthy scientist. Partnerships can also be industrially rooted, in which case they concern pioneers in specific technologies (such as the Renault-Nissan partnership on fuel cell vehicles), or they can be based on environmental projects with other large organizations that are perceived as efficient, such as Bosch, or Valeo. Exemplarity is expressed through references to rewards or awards coming from governmental entities or environmental agencies (e.g., the France Ministry for Ecology and Sustainable Development, the French Environment and Energy Control Agency, or the Japan Regulation Institute), and builds the image of the firm as a "responsible" actor. Although the cognitive references do not directly refer to profit generation, it builds heavily on the idea that green legitimacy is likely to improve an organization's image and, in turn, its brand equity.

\subsection{A firm isomorphic and standardized discourse on environmentalism}

Surprisingly, our findings suggest that there are little differences between firms' discursive strategies, and particularly in their customer-oriented communication. At the cognitive level, the three firms emphasize their in-house green labels (“eco2” for Renault; "Blue Lion" for Peugeot; "Airdream" for Citröen) and symbolize them by an iconic element (stylized green

police for Renault; green flowers for Peugeot; clouds on a blue background for Citröen). They similarly allude to their technological developments, although they wear different denominations (FAP -particulate filter- for all, Dci or Tce engines for Renault; Hdi or a Thp engines for Peugeot; Hdi engines for Citroën). They also display very conventional and evocative images where trees dominate (mountains, sea and trees for Renault; wildlife, 
mountains and trees for Peugeot; green trees for Citröen). At the pragmatic level, the three firms explain the correspondence between the level of $\mathrm{Co} 2 / \mathrm{km}$ and gas consumption, and promote their vehicles with similar techniques and names, such as "EcoJours" ("GreenDays", Renault), "EcoloReprise” (“GreenTake-back” / Citröen), or "BlueEco” Feebate (Peugeot). To emphasize their moral legitimacy, logos and short sentences within the ads are used to ensure customers that their cars are recyclable and manufactured in Iso14001 plants (Peugeot, Renault). These different elements provide support to a more abstract discourse about the environmental engagement of the firms at a product portfolio level (Renault) or at a corporate level (Peugeot and Citröen). These strong similarities can also be found in the firms'slogans ("Renault Acts" [in favor of the environment], "Concrete Action" for Peugeot, "Proactive policy in favor of the environment" for Citröen). Even in a relatively short period of observation and limited brand perimeter, such isomorphism is rather counterintuitive in a customer-oriented communication that should rather strive at differentiating the firm from its competitors.

This absence of differentiation can also be found in the shareholder-oriented communication, where firms offer few alternatives in terms of content. For example, the firms all allude to their environmentally-oriented partnerships, the only difference being the partners' identity (e.g., Ford, BMW, the French National Scientific Research Center for PSA Peugeot Citroën; Nissan and the Israeli government for Renault).

Finally, in the employee-oriented communication, the role of the organization as a green citizen, that is emphasized by introducing and discussing the organization's involvement in environmental research projects beyond what is expected from a car manufacturer (e.g., a natural carbon sink project in the Amazonian forest for PSA Peugeot Citroën and the reforestation of Turkey for Renault), is disclosed in a similar fashion. 


\section{Discussion}

\subsection{Theoretical contributions and avenues for future research}

By exploring organizations' legitimation strategies in mature markets, we contribute to extant marketing literature on legitimacy maintenance. Specifically, our research complements prior works on the discursive maintenance of legitimacy by showing that the legitimation dynamics in mature markets differ significantly from the legitimation dynamics in earlier stages of markets. In particular, our findings point to two key differences: the re-structuration of markets around key issues; and the adaptation of organizational discourses to address the different expectations of their stakeholders.

First, previous research has outlined that since new markets are in the process of being structured (Maguire, Hardy, and Lawrence 2004), they cannot build on a long history and the rules of market interactions are therefore still under construction. To ensure the sustainability of the whole market, organizations must first reach a stage of global and undifferentiated legitimacy, which implies engaging in a collective discursive legitimizing work to make the new product and the associated technologies accepted at the cognitive, moral and regulatory levels. This leads the organizations within the field to speak with one voice and without distinction towards their targeted audiences (Rosa et al., 1999).

Markets that successfully manage to develop beyond this stage enter a phase of stable maturity that is characterized by established and powerful rules (Maguire, Hardy, and Lawrence 2004). In such environments, the products are accepted and understood and markets have received general validation by the main constituents of the environment (Humphreys 2010). Once markets become mature, organizations tend to move from an undifferentiated legitimation strategy to a differentiated one, thus adopting different discursive strategies in order to gain the continuous support of their audience. In this stage of market development, 
legitimacy is essentially achieved through differentiation between organizations or brands (Rosa et al., 1999).

We suggest in our study that once mature markets become contested, they enter a third phase. Following Hoffman (1999), we argue that in this third phase of market development, the organizations' legitimation efforts are no longer primarily organized around products, services or major technologies, but that they are more prominently shaped by key issues that contribute to re-structuring the field. Established mature markets are dominated by powerful incumbents that benefit from current institutional arrangements and thus work at maintaining the status quo (Fligstein 1996). However, while being characterized by more stable and predictable transactions, mature markets and established institutions are also the objects of power struggles and contentiousness coming from external actors (King and Pearce 2010). When organizations start to interact and create relationships on the basis of a fast growing and prominent issue such as corporate environmentalism in the $2000 \mathrm{~s}$, it is because this issue has become a social norm and thus a structuring element of the field (Hoffman 1999).

This organization of markets around issues constitutes the primary difference from earlier stages of market development as it significantly impacts market actors' interactions and their positions within the market. Specifically, the way organizations address these issues may significantly alter an organization's strategy and its competitive position. And all the more so since issues are subject to change. For instance, for many years in France, diesel was assumed to be the least-environmentally damaging fuel and public authorities encouraged car producers to develop diesel-related technologies and consumers to buy diesel-powered cars (for example, thanks to the instauration of an ecological bonus/malus system favoring dieselpowered cars). This trend shifted recently when diesel cars started to receive negative publicity due to the amount of toxic emission they produced (NOx) and public authorities started to discourage their use, up to the point where diesel-powered cars will be banned from 
certain urban areas (e.g., in Paris). Although the overall issue (reducing one's ecological footprint) remains the same, the means to addressing it have completely changed, with significant impacts for the industrial production of cars. In mature contested markets, it is therefore essential for organizations to recognize important issues and adapt to their, sometimes significant, reframing.

Second, an essential characteristic of legitimation strategies in mature contested markets rests on the differentiation of organizations' discourses with regards to their different stakeholders. As discussed earlier, organizations in new markets tend to develop undifferentiated discourses: their discourses are similar and they do not distinguish between different audiences. This lack of differentiation with regards to audiences is still a characteristic of organizations in stable mature markets, although these organizations try to differentiate from one another. We show that in mature contested markets, organizations rely on differentiated discursive strategies depending on the stakeholders they target, which stands in contrast with previous research that tends to look at organizational responses to institutional pressures (such as environmentalism) as undifferentiated (e.g., Elsbach 1994; Menon and Menon 1997). Building on Scherer and Palazzo (2007)'s claim that organizations can best develop and maintain their legitimacy by engaging in dialogue with their stakeholders, we investigate how organizations take the specificity of their multiple audiences into account and accordingly adapt their discourses.

When addressing customers, organizations seem to favor an individuation-based discursive strategy. Such discourses emphasize the extent to which the environmental efforts and actions carried out by the firm can constitute resources customers can use in their quest to affirm themselves. When consuming a product, customers consume both its "use value" and its "status value" (Woodall 2003). The use value of a good stands for the specific qualities of this good, as perceived by the customer in relation to his own needs (Kumar and Reinartz 
2016). The status value is more symbolic (but no less utilitarian) and refers to the worth and prestige that is attached to the good and that is subsequently captured by the customer. Our findings reveal that by focusing on three aspects of the customer's self through the projected image of a good, smart, and aware customer, organizations convey the message that owning and driving a green car satisfies both the "use" and "status" value expectations of the customer. Surprisingly and somewhat counterintuitively, customer-targeted discourses deemphasize the moral dimension of the environmental legitimacy and rather elect to appeal to consumers' individual choices rather than to collective achievements.

When addressing employees, organizations tend to employ an affiliation-based discourse. Prior research has suggested that perceived external prestige (i.e., how employees think others view and evaluate their organizations and, subsequently, how they view and evaluate themselves as members of that organization) significantly affects organizational identification (Glavas and Godwin, 2013; Smidts, Pruyn, and Van Riel 2001). If employees perceive that their organization benefits from a positive image in the eyes of important external constituents, they feel proud and sense they belong to it. Our study shows that organizations build heavily on the employees' sense of pride and belonging as a way to increase their affiliation to the organization. By emphasizing the moral, pragmatic, and cognitive aspects of their environmental behavior, organizations increase their employees' overall sense of affiliation (1) at the affective level, through the depiction of the organization as an environmentally responsible citizen to be proud of; (2) at the cognitive level, through better exposure of the employees to key environmental actions of the organization and through enhancement of the employees' participation in these actions, both enhancing employee's identification to the organization (Ashforth and Mael 1989).

When addressing shareholders, organizations rely on a performance assertion discourse, thus seeking to demonstrate factually that they have already obtained a number of 
results in relation to environmentalism. Shareholders and financial analysts are often primarily concerned with the organization's performance, either in terms of opportunities for economic profit or in terms of market returns. However, the question of whether "it pays to be green" is still a hotly debated issue at both the academic and social levels. Indeed, a number of empirical studies investigating the impact of environmental activities on economic performance or market returns have reached diverging verdicts (e.g., Martín de Castro, Amores-Salvadó, and Navas-López, 2016). Because the organization is facing considerable pressures on how to allocate its corporate resources, it needs to convince its shareholders that its environment-related expenditures do not constitute an unnecessary drain on resources that could otherwise have been invested profitably. That is, the organization needs to convince its shareholders that there is no trade-off involved between environmentally responsible behavior and profitability. A crucial issue is therefore to convince this audience that investing in environmental activities is not only a necessity (due to the strong pressures emanating from the institutional environment) but that it may also provide business opportunities in terms of cost reductions or increased competitiveness.

Paradoxically and in contrast to these audience-differentiated strategies, we find strong evidence of field isomorphism when it comes to these organizations' environmental discourses. Although prior studies have shown that in mature and stable markets organizations tend to differentiate themselves from their competitors and build unique positionings (e.g., Rosa et al. 1999), we find that in mature but contested markets, organizations tend to adopt industry-wide standardized discourses rather than idiosyncratic ones, thereby indicating a common understanding of the issue they collectively face. These findings converge with the conclusion of a forthcoming paper by Feix and Philippe (In Press), which finds that institutional CSR narratives that aim at promoting the CSR institution are characterized by a common "wa[y] of talking” (Fairclough 2013; Reisigl and Wodak 2009). 
The authors show how these institutional narratives "resort to the same topoi as well as to similar wordings and sentence structures" (Feix and Philippe In press, p. 24) and suggest that these discursive regularities point to the existence of a self-replicating metanarrative (Lyotard 1984).

Figure 2 below summarizes how legitimation dynamics differ depending on the stage of development of the market. Such a dynamic approach on legitimacy processes raises several questions and avenues of future research. First, although we focus on this paper on the discursive strategies developed by organizations when an issue emerges as an object of contestation and debate in a mature market, our period of observation (three years) is limited. It would therefore be interesting to examine organizations' legitimation strategies once the issue has become fully institutionalized and embedded within the market. For instance, does it give rise to a fourth stage of market development? And what would be the implications in terms of legitimation dynamics? One possibility would be that the institutionalization of the issue would lead to the reactivation of direct competition between organizations. Another promising avenue of future research would be to adopt a more longitudinal perspective and investigate these different stages in legitimation dynamics (construction; reinforcement; maintenance) in the scope of one study. Finally, one limitation of this research is its focus on one issue within one industry. To introduce a richer understanding of legitimacy maintenance in mature markets, further research could conduct inter-industry and inter-issue comparisons in order to generalize and possibly extend the legitimation pattern we find.

Insert Figure 2 about here

\subsection{Managerial implications}


In addition to the theoretical contributions developed above, this research has important managerial implications. In particular, our findings suggest that managers should pay particular attention to balancing legitimacy and reputation imperatives when designing their organizational discursive strategies.

Framing strategies are useful tools that organizations can use to present a particular image of the self (Bansal and Kistruck 2006; Bolino 1999) and ultimately gain social support from their audiences (Fiss and Zajac 2006). The largely positive tenor of the media coverage of our three brands with regards to their respective environmental actions is proof that the adaptation of discourses (i.e., the use of differentiated framings) to the organization's different stakeholders is an efficient means of legitimizing it in the eyes of its audiences and gaining this social approval.

Based on our findings, we believe that managers should avoid restricting their strategies to one type of discourse per stakeholder but should instead develop a varied discursive repertoire. When targeting customers, for instance, managers could deploy a mixture of corporate- and product-based communication: at the corporate level by emphasizing the industry or organization's efforts to reduce its ecological footprint (as Peugeot and Renault did when communicating about building ISO14001 plants) and at the product level by explaining how the organization's products contribute to the organization's environmental stewardship.

Our findings also show that moral legitimacy is scarcely used by organizations when discussing their efforts towards environmental stewardship. Organizations tend to rely more on cognitive and pragmatic perspectives by clarifying the different actions they carry out and the results they achieve (cognitive legitimacy) or demonstrating how their efforts are beneficial to all their constituents (pragmatic legitimacy). We believe that organizations would benefit from deploying a more balanced discursive repertoire and specifically in 
building more on moral legitimacy. For instance, leveraging this moral aspect would allow the organizations' stakeholders to make better sense of the organization's accomplishments (e.g., development of less-polluting technologies or labels, engagement in environmental projects, etc.) and the organizations to increase their visibility and prestige.

Additionally, although the adaptation of discourses to their targeted audience is a central element of the legitimation strategy, we propose that it is essential for these discourses to create a sense of coherence and avoid inconsistencies. When designing their general discursive strategy, managers should identify core and peripheral elements. The core elements would be deployed in a similar fashion across all stakeholders while the peripheral (and maybe more concrete) elements would be adapted to the specific stakeholders' expectations.

An essential pitfall to avoid is the reproduction of conventionalized discourses (Feix and Philippe In press). Although the quest for legitimacy often calls for isomorphic behaviors (DiMaggio and Powell 1983; Deephouse 1996), this may ultimately be detrimental to the organization's reputation. Research in strategy has abundantly discussed how organizations should strategically balance the need to be the same with the need to be different (e.g., Deephouse, 1999; Porac, Thomas, and Baden-Fuller 1989). Abrahamson and Hegeman (1994) for instance observe that conformity or isomorphism reduces opportunities for competitive advantage. Although some degree of similarity in communication practices across organizations is essential to blend in, it is equally important for their competitive advantage and reputation that organizations stand out from their competitors on how they give sense to a focal issue. In the context we studied, we saw some attempts at differentiation between strategic groups. 2006 was the beginning of industry-wide discussions regarding the European Commission's agenda to reinforce the constraints in term of $\mathrm{CO} 2$ emissions. This agenda was publicly contested by German carmakers, which produce high-end and large vehicles. It was however supported by French and Italian carmakers (which produce small 
and medium urban cars). However, we saw no differentiation between organizational discursive strategies. We therefore encourage managers to build on the values, identity and heritage of their organization to develop a differentiated and embodied approach, and to take ownership of the issue.

\section{Conclusion}

At a broader level, this research speaks to the growing literature on CSR communication (see Schoeneborn, Morsing and Crane, In Press for a recent review) and more specifically to the body of research looking at how organizations communicate on their CSR practices to promote their legitimacy or reputation (e.g., Carlos and Lewis 2018; Ferrell, GonzalesPadron, Hult and Maignan 2010; Philippe and Durand 2011; Sen, Bhattacharya and Korschun 2006). It is, however, important not to restrict our understanding of CSR communication to a mere legitimacy management tool and keep in mind that the CSR texts produced by organizations may have transformative and performative effects on both the communicationissuing organization and its audiences (e.g., Livesey 2001; Morsing and Schultz, 2006).

Organizations' CSR discourses should not be designed as unilateral instances of issue sensegiving but as real symmetric dialogues around these issues so that they can fulfill their potential of becoming key drivers of organizational and societal change (Scherer and Palazzo 2007; Palazzo and Scherer 2006).

\section{References}

Abrahamson. E., \& Hegeman. R. (1994). Strategic conformity: An institutional theory explanation. Paper presented at the Academy of Management Conference, Dallas 
Ashforth, B. E., \& Mael, F. (1989). Social identity theory and the organization. Academy of Management Review, 14(1), 20-39.

Banerjee, S. B. (2002). Corporate environmentalism: The construct and its measurement. Journal of Business Research, 55(3), 177-191.

Banerjee, S. B., Iyer, E. S., \& Kashyap, R. K. (2003). Corporate environmentalism: antecedents and influence of industry type. Journal of Marketing, 67(2), 106-122.

Bansal, P., \& Kistruck, G. (2006). Seeing is (not) believing: Managing the impressions of the firm's commitment to the natural environment. Journal of Business Ethics, 67, 165-180. Berens, G., Riel, C. B. V., \& Bruggen, G. H. V. (2005). Corporate associations and consumer product responses: The moderating role of corporate brand dominance. Journal of Marketing, 69(3), 35-48.

Bhattacharya, C. B., Rao, H., \& Glynn, M. A. (1995). Understanding the bond of identification: An investigation of its correlates among art museum members. Journal of Marketing, 46-57.

Bolino, M. C. (1999). Citizenship and impression management: Good soldiers or good actors? Academy of Management Review, 24, 82-98.

Carlos, C.W. \& Lewis, B.W. (2018), Strategic Silence: Withholding Certification Status as a Hypocrisy Avoidance Tactic, Administrative Science Quarterly, 63(1), 130-169.

Czinkota, M., Kaufmann, H. R., \& Basile, G. (2014). The relationship between legitimacy, reputation, sustainability and branding for companies and their supply chains. Industrial Marketing Management, 43(1), 91-101.

Dawkins, J., \& Lewis, S. (2003). CSR in stakeholder expectations: And their implication for company strategy. Journal of Business Ethics, 44(2-3), 185-193.

Deephouse, D. L. (1996). Does isomorphism legitimate? Academy of Management Journal, 39(4), 1024-1039. 
Deephouse, D. L. (1999), To be different, or to be the same? It's a question (and theory) of strategic balance, Strategic Management Journal, 20(2), 147-166.

Deephouse, D. L. (2000). Media reputation as a strategic resource: An integration of mass communication and resource-based theories. Journal of Management, 26(6), 1091-1112. DiMaggio, P., \& Powell, W. W. (1983). The iron cage revisited: Collective rationality and institutional isomorphism in organizational fields. American Sociological Review, 48(2), 147160.

Dunfee, T. W., Smith, N. C., \& Ross Jr, W. T. (1999). Social contracts and marketing ethics. Journal of Marketing, 63(3), 14-32.

Elsbach, K. D. (1994). Managing organizational legitimacy in the California cattle industry: The construction and effectiveness of verbal accounts. Administrative Science Quarterly, $39(1), 57-88$.

Ertimur, B., \& Coskuner-Balli, G. (2015). Navigating the institutional logics of markets: Implications for strategic brand management. Journal of Marketing, 79(2), 40-61.

Fairclough, N. (2013). Critical discourse analysis: The critical study of language. London, England: Routledge.

Fairclough, N. (2003). Analysing discourse: Textual analysis for social research. Psychology Press.

Feix, A. (2018). A critical investigation into the corporate social responsibility discourse. $P h D$ Dissertation, University of Lausanne.

Feix, A. \& Philippe, D. (forthcoming), Unpacking the Narrative Decontestation of CSR: Aspiration for Change or Defense of the Status Quo? Business \& Society, published online December 3, 2018.

Ferrell, O.C., Gonzalez-Padron, T.L., Hult T.M. \& Maignan, I. (2010) From Market Orientation to Stakeholder Orientation, Journal of Public Policy \& Marketing, 29(1), 93-96 
Fligstein, N. (1996). Markets as politics: A political-cultural approach to market institutions. American Sociological Review, 656-673.

Fiss, P. C., \& Zajac, E. J. (2006). The symbolic management of strategic change: Sensegiving via framing and decoupling. Academy of Management Journal, 49(6), 1173-1193.

Giesler, M., \& Fischer, E. (2017). Market system dynamics. Marketing Theory, 17(1), 3-8. Glavas, A., \& Godwin, L. N. (2013). Is the perception of 'goodness' good enough? Exploring the relationship between perceived corporate social responsibility and employee organizational identification. Journal of Business Ethics, 114(1), 15-27.

Golant, B. D., \& Sillince, J. A. (2007). The constitution of organizational legitimacy: A narrative perspective. Organization Studies, 28(8), 1149-1167.

Haws, K. L., Winterich, K. P., \& Naylor, R. W. (2014). Seeing the world through GREEN-tinted glasses: Green consumption values and responses to environmentally friendly products. Journal of Consumer Psychology, 24(3), 336-354.

Hoffman, A. J. (1999). Institutional evolution and change: Environmentalism and the US chemical industry. Academy of Management Journal, 42(4), 351-371.

Humphreys, A. (2010). Megamarketing: The creation of markets as a social process. Journal of Marketing, 74(2), 1-19.

Humphreys, A., Chaney, D., \& Slimane, K. B. (2017). Megamarketing in Contested Markets: The Struggle between Maintaining and Disrupting Institutions. Thunderbird International Business Review, 59(5), 613-622.

Humphreys, A., \& Latour, K. A. (2013). Framing the game: Assessing the impact of cultural representations on consumer perceptions of legitimacy. Journal of Consumer Research, 40(4), $773-795$.

King, B. G., \& Pearce, N. A. (2010). The contentiousness of markets: Politics, social movements, and institutional change in markets. Annual Review of Sociology, 36, 249-267. 
Kotter, J. P. \& Heskett, J. L. (1992). Corporate culture and performance. New York: Free Press.

Kostova, T., \& Zaheer, S. (1999). Organizational legitimacy under conditions of complexity: The case of the multinational enterprise. Academy of Management Review, 24(1), 64-81.

Krippendorf, K. (1980). Content analysis: An introduction to its methodology. Beverly Hills, CA: Sage.

Kumar V. and Reinartz W. (2016), Creating enduring customer value, Journal of Marketing, 80(6), 36-68.

Livesey, S. M. (2001). Eco-Identity as Discursive Struggle: Royal Dutch/Shell, Brent Spar, and Nigeria. The Journal of Business Communication (1973), 38(1), 58-91.

Lounsbury, M., \& Glynn, M. A. (2001). Cultural entrepreneurship: Stories, legitimacy, and the acquisition of resources. Strategic Management Journal, 22(6-7), 545-564.

Lyotard, J. F. (1984). The postmodern condition: A report on knowledge (Vol. 10).

Minnesota, MN: University of Minnesota Press.

Maguire, S., \& Hardy, C. (2009). Discourse and deinstitutionalization: The decline of DDT. Academy of Management Journal, 52(1), 148-178.

Maguire, S., Hardy, C., \& Lawrence, T. B. (2004). Institutional entrepreneurship in emerging fields: HIV/AIDS treatment advocacy in Canada. Academy of Management Journal, 47(5), 657-679.

Maignan, I., \& Ferrell, O. C. (2004). Corporate social responsibility and marketing: An integrative framework. Journal of the Academy of Marketing Science, 32(1), 3-19.

Martin, D. M., \& Schouten, J. W. (2013). Consumption-driven market emergence. Journal of Consumer Research, 40(5), 855-870.

Martín-de Castro, G., Amores-Salvadó, J., \& Navas-López, J. E. (2016). Environmental management systems and firm performance: improving firm environmental policy through 
stakeholder engagement. Corporate social responsibility and Environmental Management, 23(4), 243-256.

Menon, A., \& Menon, A. (1997). Enviropreneurial marketing strategy: the emergence of corporate environmentalism as market strategy. Journal of Marketing, 61(1), 51-67.

Morsing, M., \& Schultz, M. (2006). Stakeholder Communication Strategies. In M. Morsing, \& S. C. Beckmann (Eds.), Strategic CSR communication (pp. 135-160). Copenhagen: Djøf Forlag.

Oliver, C. (1991). Strategic responses to institutional processes. Academy of Management Review, 16(1), 145-179.

Palazzo, G., \& Scherer, A. G. (2006). Corporate legitimacy as deliberation: A communicative framework. Journal of Business Ethics, 66, 71-88.

Palmer, M., Simmons, G., Robinson, P. K., \& Fearne, A. (2015). Institutional maintenance work and power preservation in business exchanges: Insights from industrial supplier workshops. Industrial Marketing Management, 48, 214-225.

Patriotta, G., Gond, J. P., \& Schultz, F. (2011). Maintaining legitimacy: Controversies, orders of worth, and public justifications. Journal of Management Studies, 48(8), 1804-1836. Philippe, D., \& Durand, R. (2011). The impact of norm-conforming behaviors on firm reputation. Strategic Management Journal, 32(9), 969-993.

Phillips, N., Lawrence, T. B., \& Hardy, C. (2004). Discourse and institutions. Academy of Management Review, 29(4), 635-652.

Porac, J.F., Thomas H., \& Baden-Fuller C. (1989), Competitive groups as cognitive communities: The case of Scottish knitwear manufacturers, Journal of Management Studies, 26(4), 397-416.

Powell, W. W., \& DiMaggio, P. J. (1991). The new institutionalism in organizational analysis. Chicago, IL: University of Chicago Press. 
Rosa, J. A., Porac, J. F., Runser-Spanjol, J., \& Saxon, M. S. (1999). Sociocognitive dynamics in a product market. Journal of Marketing, 64-77.

Rao, H. (2002). 'Tests tell': Constitutive legitimacy and consumer acceptance in the American automobile industry: 1985-1912. In P. Ingram \& B. Silverman (Eds.), The New institutionalism in strategic management (pp. 307-339). Stamford, CT: JAI Press.

Reisigl, M., \& Wodak, R. (2009). The Discourse-Historical Approach (DHA). In R. Wodak \& M. Meyer (Ed.), Methods of critical discourse analysis (2nd Rev. ed., pp. 87-121). London, England: SAGE.

Scaraboto, D., \& Fischer, E. (2012). Frustrated fatshionistas: An institutional theory perspective on consumer quests for greater choice in mainstream markets. Journal of Consumer Research, 39(6), 1234-1257.

Scherer, A.G. \& Palazzo G. (2007), Toward a political conception of corporate responsibility: Business and society seen from a habermasian perspective, Academy of Management Review, 32(4), 1096-1120.

Schoeneborn, D., Morsing M., \& Crane, A. (forthcoming), Formative perspectives on the relation between CSR communication and CSR practices: pathways for walking, talking, and t(w)alking, Business \& Society, published online May 7, 2019.

Sen, S., Bhattacharya C.B., \& Korschun D. (2006), The role of corporate social Responsibility in strengthening multiple stakeholder relationships: a field experiment, Journal of the Academy of Marketing Science, 34(2), 158-166.

Sharma, A., Iyer, G. R., Mehrotra, A., \& Krishnan, R. (2010). Sustainability and business-tobusiness marketing: A framework and implications. Industrial Marketing Management, 39(2), 330-341. 
Smidts, A., Pruyn, A. T. H., \& Van Riel, C. B. (2001). The impact of employee communication and perceived external prestige on organizational identification. Academy of Management Journal, 44(5), 1051-1062.

Strauss, A., \& Corbin, J. M. (1990). Basics of qualitative research. Thousand Oaks, CA: Sage Publications, Inc.

Suchman, M. C. (1995). Managing legitimacy: Strategic and institutional approaches. Academy of Management Review, 20(3), 571-610.

Suddaby, R., \& Greenwood, R. (2005). Rhetorical strategies of legitimacy. Administrative Science Quarterly, 50(1), 35-67.

Tajfel, H. (1982). Social psychology of intergroup relations. Annual Review of Psychology, 33(1), 1-39.

Weber, P. (1985). Content analysis: Quantitative applications in the social sciences. Beverly Hills: Sage Publications.

Wilmshurst, T. D., \& Frost, G. R. (2000). Corporate environmental reporting: A test of legitimacy theory. Accounting, Auditing \& Accountability Journal, 13(1), 10-26.

Woodall, T. (2003). Conceptualizing 'value for the customer': An attributional, structural and dispositional analysis. Academy of Marketing Science Review, 2003, 1.

Yang, Z., \& Su, C. (2014). Institutional theory in business marketing: A conceptual framework and future directions. Industrial Marketing Management, 43(5), 721-725.

Zuckerman, E. W. (1999). The categorical imperative: Securities analysts and the illegitimacy discount. American Journal of Sociology, 104(5), 1398-1438.

\section{Footnotes}

1. Source: Factiva (2/2/2017): based on the following keywords -France, industry, automobile- with a restriction on the source - energy and automotive sectors- the number of articles dealing with environmentalism went from 1191 (2000-2003) to 2909 (2003-2006) and 5248 (2006-2009), revealing 
the sharpest increase within the last two decades before a relative stabilization (5730 on the 2012/14 period for instance)

2. Note that a single ad may be inserted several times across magazines, which explains the difference between the number of ads and the total number of insertions in magazines.

3. We exclusively focused on the narrative sections of the annual reports as we were not interested in the highly standardized and audited discourses present in the Managerial Discussion and Analysis (MD\&A) and financial sections of these reports.

4. Note that the ads and newsletters were in French, while the annual reports were in English. For the sake of reliability, we performed the content-analysis on the original versions of each document and later translated the ads and newsletters' environmental disclosures into English to provide comparable texts. 
TABLE 1. Environmental issues in the French press

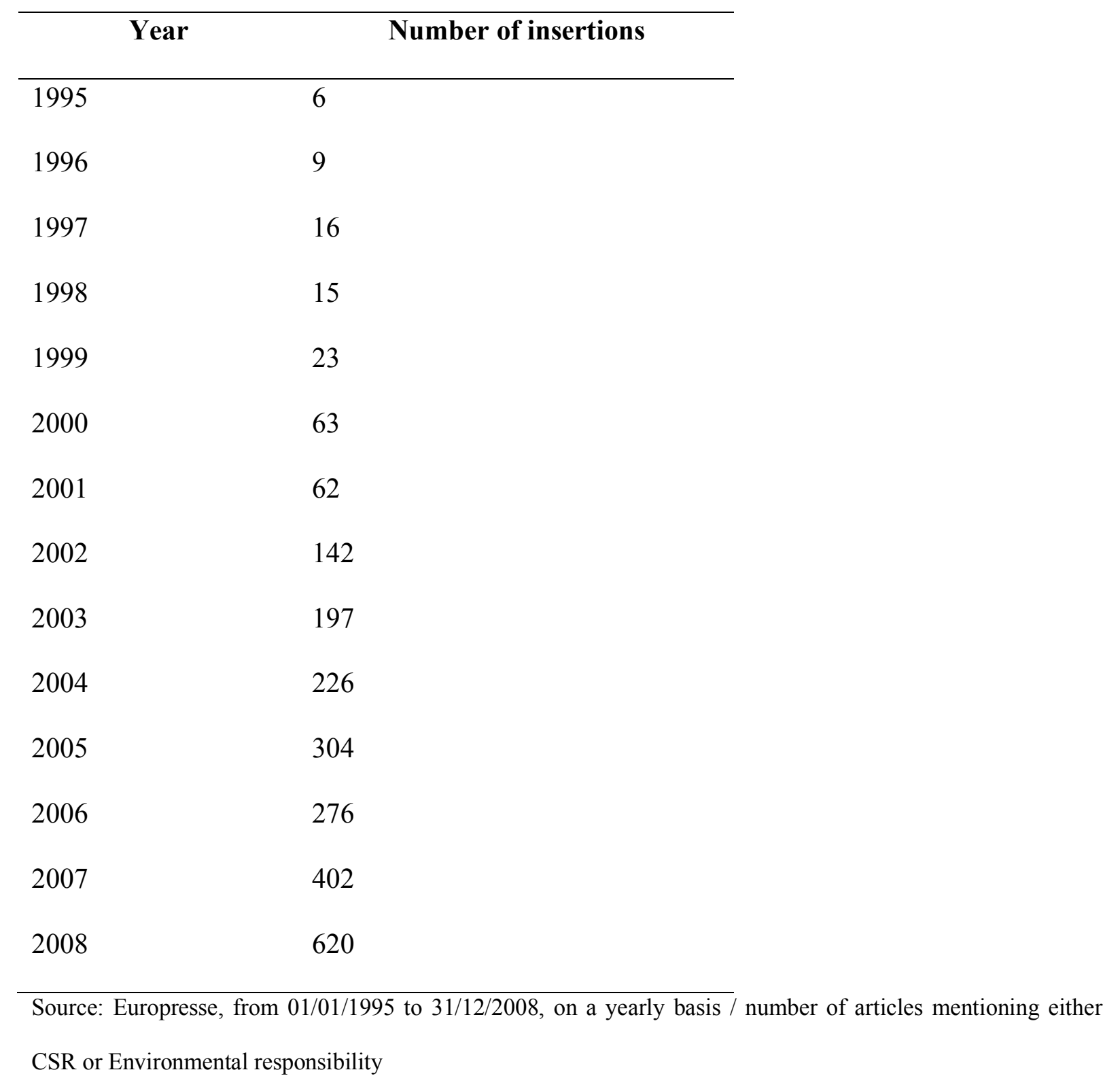


TABLE 2. Descriptive statistics

\begin{tabular}{lllll}
\hline & Customer- & Employee- & Shareholder- & Total \\
& targeted & targeted & targeted & \\
& legitimation & legitimation & legitimation & \\
& strategy & strategy & strategy & \\
& & & $19(4 \%)$ & 237 \\
\hline Moral & $177(23 \%)$ & $41(24 \%)$ & $135(31 \%)$ & 464 \\
\hline Pragmatic & $271(35 \%)$ & $58(33 \%)$ & $283(65 \%)$ & 688 \\
\hline Cognitive & $330(42 \%)$ & $75(43 \%)$ & 437 & 1389 \\
\hline
\end{tabular}


TABLE 3. Illustrative quotations

Customer-targeted legitimation strategy

Moral

Take advantage of our clean promotion: Nature
will remember. (PSA Peugeot Citroën)

To leave a lighter ecological footprint is our commitment with eco2. (Renault)

Leaving fewer traces on the planet is Renaul Eco2's commitment. For more than 15 years, Renault has been working to reduce the impact of its activities on the environment. With Renault Eco2, Renault is committed to using more respectful factories. (Renault)

To further protect the environment, Peugeot has developed four gasoline engines for the 207 models. (Peugeot)

Blue Lion. Reduce your carbon footprint (Peugeot)

Peugeot is committed to reducing polluting and greenhouse gas emissions through concrete actions. (Peugeot)

\section{Employee-targeted legitimation strategy}

To emphasize the importance of recycling, Oyak-

Renault presented 58 works realized from recycled

IT elements. In addition, each employee of the Turkish company received a certificate indicating that a tree had been planted for him in the Green Millenium forest. (Renault)

Peugeot's forest carbon sink project in Amazonia is a unique project (...). In terms of carbon-capture oriented reforestation, this project epitomizes a biodiversity that is unmatched in the world. (PSA Peugeot Citroën)

Preserving the planet is the duty of everyone, individuals and companies. On April 12, Renault hosted the famous astrophysicist Hubert Reeves for a conference. In front of a packed room, the scientist gave the keys to restore the fragile balance between what he calls the 3Ps: profit, people, planet. (Renault)

The Sochaux site has launched a company travel plan to reorganize the travel of its employees and partners. Through this action, the group has undertaken to divide by 20 the number of cars entering the site with the French Committee for the Environment and Sustainable Development. (PSA Peugeot Citroën)

\section{Shareholder-targeted legitimation strategy}

Two million saplings have been planted over the last ten years in the carbon sink developed by Peugeot and France's national forest service, ONF, in the Amazon basin. The 2,000 hectares replanted with local species have already sequestered 51,000 metric tons of $\mathrm{CO} 2$. This life-size laboratory is enabling scientists to verify the relationship between reforestation, carbon capture and climate change. (PSA Peugeot Citroën)

Renault wants to help drivers learn to reduce $\mathrm{CO} 2$ emissions. We have, for example, created a Q\&A game with the French Agency for Environment and Energy Management (ADEME), which explains global warming and the link between how we use our cars and the volume of $\mathrm{CO} 2$ we produce. (Renault)

The greenhouse effect is a natural phenomenon that keeps the Earth at a liveable temperature. However, emissions of $\mathrm{CO} 2$ and other greenhouse gasses (GHG) from human activity have risen steadily since the mid-19th century, adding to the natura effect. There is a broad consensus in the scientific community that the Earth's average temperature is rising as a result of this situation. Because internal combustion engines burn fossil fuels, the transportation industry is a significant source of GHG emissions. For PSA Peugeot Citroën, the major challenge is to continue reducing its vehicles' contribution to the greenhouse effect. The health consequences of air pollution are also becoming a key concern, especially in large city centres. That's why the Group is working to eliminate regulated contaminants like NOx, HC and particulates from tailpipe emissions and to ultimately introduce zeroemission vehicles. (PSA) 
Pragmatic Consume less and pay less with the HDI engine. (PSA Peugeot Citroën)

Combine environmental friendliness and pleasure when driving. (PSA Peugeot Citroën)

At the moment, consume less and pay less with HDI engines: 750 euros of green bonuses (Citroën)

A new gasoline technology. High performance from low revs with the twin-scroll high-pressure turbo, remarkable efficiency combined with controlled fuel consumption and $\mathrm{CO} 2$ emission thanks to direct injection: what a pleasure. (Peugeot)

$137 \mathrm{~g}$ of $\mathrm{CO} 2 / \mathrm{km}$. It is taking action for Nature. 3000 euros of trade-in. It is taking action for you. (Renault)
During all this period, our motto was to find the best efficiency for both vehicles' components and piloting in order to lower vehicles' consumption and therefore their $\mathrm{CO} 2$ emissions. (PSA Peugeot Citroën)

With our new painting installations, we are already beyond compliance to the norms that apply to the site (...). The norms will become more stringent in the future, and we need to get ready for them and anticipate their evolution. (Renault)

We must reduce our electricity and gas consumption in the face of ever-increasing energy prices and to protect the environment. This requires the exemplarity behavior and commitment of all parties (PSA Peugeot Citroën)

In order to improve air quality, the European Union is introducing precise regulations. From 2009, new vehicles will have to comply with the Euro 5 regulation. Within the group, everything is in place to meet this technical and economic challenge. (PSA Peugeot Citroën)

As Jean-Gabriel Dally, head of environmental approvals, explains: "It's the law, we must respect it in order to market our vehicles." (PSA Peugeot Citroën)
Driven by the Group's commitment to social responsibility, proven innovation capabilities and strategy for the years ahead (which includes maintaining environmental leadership), this approach [environmental management] is designed to help PSA Peugeot Citroën return to profitable growth. (PSA Peugeot Citroën)

This proactive policy has led to a spectacular reduction in energy consumption. (PSA Peugeot Citroën)

The C3 PICASSO delivers superior environmenta and cost performance with innovative style. Its low $\mathrm{CO} 2$ emissions rival with the best the competition has to offer (PSA)

We also started up a variety of programs to prepare for stricter standards in Europe, particularly with regards to $\mathrm{CO} 2$ emissions. (Renault)

Over the last ten years, environmental managemen policies at industrial facilities have cut: energy consumption by $25 \% \quad(\mathrm{~kW} /$ vehicle $)$; water consumption by $61 \%(\mathrm{~m} 3 /$ vehicle $)$, or 10 million $\mathrm{m} 3$; waste by $64 \%$ (kg/vehicle). (Renault)

The turbocharged gasoline engine range meets ever increasing market demand for fuel-efficient and environmentally- friendly engines that can comply with the Euro 5 standard. (Renault) 
Cognitive Everybody talks about ecology: Renault does something about it. (Renault)

Thanks to voluntary policy in favor of the environment's preservation. (PSA Peugeo Citroën)

Manufactured in an ISO14001 certified plant. (Renault)

Provided with a particulate filter that captures and destroys most of noxious particles and black smoke, HDI engines participate in the preservation of the environment. (PSA Peugeo Citroën).

Protecting the environment is not just about words. It means providing customers with vehicles that are affordable and will have mino effects on the environment during their life cycle. That is why Renault has created the 'Renault eco2' signature. (Renault)
In the field of car recycling, Renault is the first constructor to get involved as strongly and directly with its value chain partners. (Renault)

Today, the group is the leader on the category of ecological cars. (PSA Peugeot Citroën)

Peugeot and Citroën launched their own environmental labels - respectively 'Blue Lion' and 'Airdream' - with the same objective: show in a visible way the brands' commitment to reduce a car's environmental impacts during its entire life cycle. (PSA Peugeot Citroën)

"Responsible attitude" is part of the DNA of PSA. (PSA Peugeot Citroën)

As part of the Paris Agricultural Show, Renault exhibited a Clio 1.6 16V Hi-flex on the stand of the "Collective des céréales." (...) Totally flexible, its engine runs on a fuel that can contain a mixture of 0 to $100 \%$ petrol or Ethanol. In Europe, biofuels are also one of the most effective ways to reduce $\mathrm{CO} 2$ emissions. (Renault)
Over the years, the Group has gained a worldwide reputation for its environmental leadership. In 2008, it sold more than one million vehicles emitting less than 140 grams of $\mathrm{CO} 2$ per $\mathrm{km}$ for the third consecutive year. (PSA Peugeot Citroën)

In Brazil, we are working with Ladetel, a local clean technologies laboratory specialized in biofuels, to conduct trials of a biodiesel made from fully renewable fuel sources, such as soybean, palm, and castor oil. (PSA Peugeot Citroën)

The French Environmental and Energy Contro Agency (ADEME) publishes a list of carmakers ranked according to the level of $\mathrm{CO} 2$ emissions of their vehicle ranges. In 2007, it recognised the performance of the Group inasmuch as the average emissions of Peugeot and Citroën vehicles do not exceed $140 \mathrm{~g}$ of $\mathrm{CO} 2$ per $\mathrm{km}$, whereas the average for vehicles sold on the French market is $149 \mathrm{~g}$ of $\mathrm{CO} 2$ per $\mathrm{km}$ (refers to data in May 2007). (PSA)

Renault thus received the eco-design prize for the Modus dashboard in 2005, and was awarded the "Environmental Management for Sustainable Development" prize by the French Ministry of Ecology and Sustainable Development (one of the Ministry's "Companies and Environment" awards) in 2006. (Renault)

The Group is working on different cells and prototypes with an internal team of specialists and expert networks set up as a result of research partnerships - like those concluded with the French National Scientific Research Centre (CNRS) and the Atomic Energy Commission (CEA). (PSA) 
FIGURE 1. Discursive strategies underlying the maintenance of legitimacy towards the main actors of the field

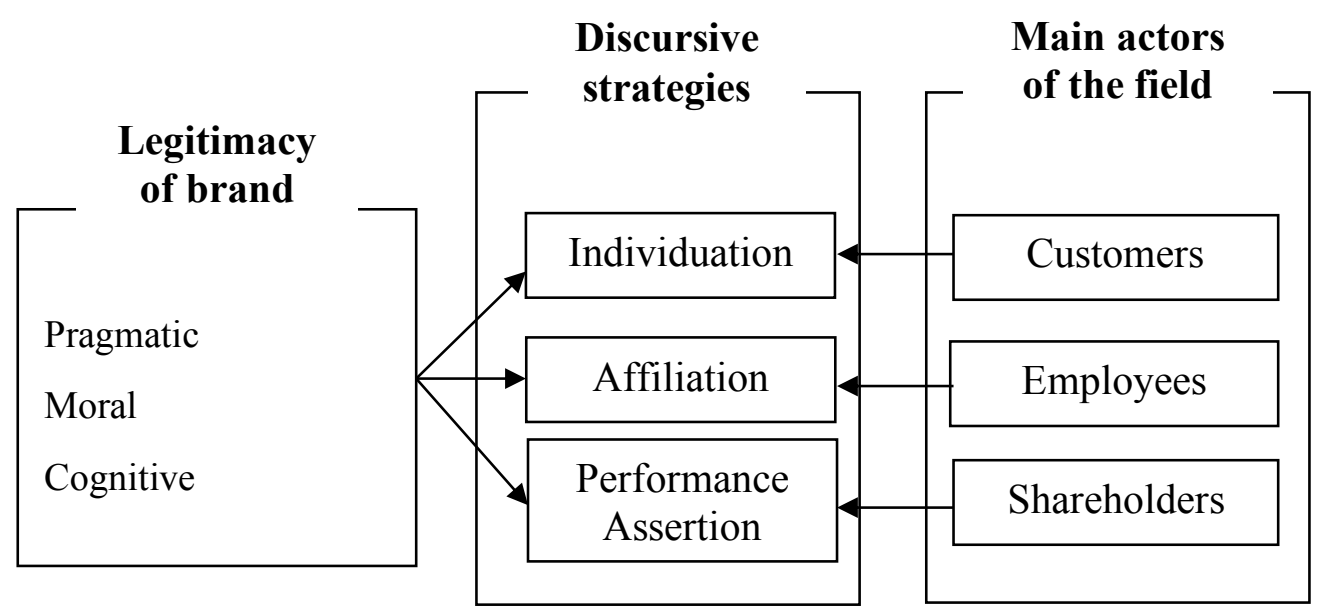


FIGURE 2. Legitimation dynamics across different stages of market development

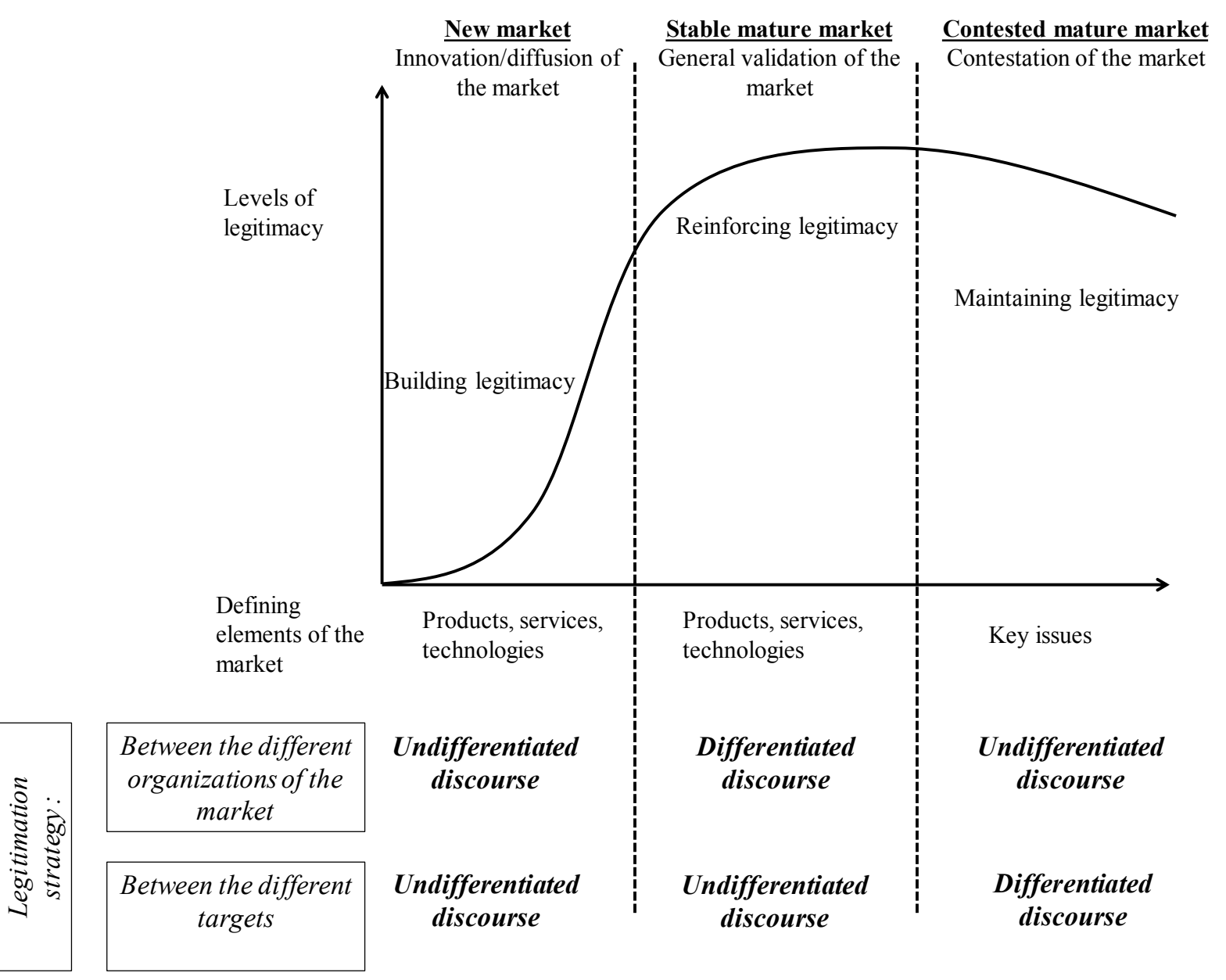

